\title{
The $2^{\text {nd }}$ TEYLIN International Conference \\ April 2017
}

\section{INDONESIAN CULTURE-BASED COMIC FOR TEACHING YOUNG LEARNERS IN INDONESIA}

\author{
Herlina Muryan Saputri \\ saputriherlina2@gmail.com \\ Student of English Education Department of Muria Kudus University
}

\begin{abstract}
English has a central role in the development of intellectual, social, and emotional of learners in supporting the success of learning. Indonesian government has made an effort to improve learners' English proficiency by introducing English earlier in formal educational which is from primary school level or even the Early Childhood Education (ECD). However, based on the research from the English Proficiency Index (EPI) which measures the average level of English language (November, $5^{\text {th }} 2015$ ) the position of English proficiency in Indonesia is still very low at 32 from total of 72 countries in 2015 and 2016. The position represents a decline from the year in 2014. The other weakness of Indonesian's people is less knowledge and insight about Indonesia culture in modern era. Therefore, it needs a new innovation in English language teaching. The alternative proposed is using Indonesian culture-based comic with more picture and less dialogue. It is believed to be more interesting than conventional way. The present research uses qualitative methods with literature approach. The data will be collected through the senses and get some additional information through internet or books. This research is aimed describing comic as an alternative media to combine culture insight in Teaching English for Young Learners. The using of Indonesian CultureBased Comic for Teaching Young Learners in Indonesia is expected to educate Indonesia people about diversity which is spread throughout Indonesia. They will be easy to use English for communication.

Keywords: Culture, Comic, Teaching English for Young Learners
\end{abstract}

\section{INTRODUCTION}

In $21^{\text {st }}$ century, the national education system faces challenges are very complex in preparing quality of Human Resources in order to compete in the global era. One of them is foreign language skills, especially English. Based on the results of the study English Proficiency Index (EPI) 2016, Indonesia gets ranks $32^{\text {nd }}$ of 72 countries in the world. The figure represents a decline from 2014. This demonstrates that the quality of English is still in the middle level in Indonesia

Based on the Education and Culture Minister Number 060 / U / 1993, February 25, 1993 (Department of Education and Culture, 1993), English Learning is taught as a local content subjects in primary schools and it started in the fourth grade of elementary school. English based curriculum in 2013 was abolished in order to strengthen the students' ability in Indonesia language and learn Indonesia culture before they learn a foreign language. It was stated by Musliar Kasim, Vice Education and Culture Minister "There is no English education in Elementary School, because they still do not understand well about Indonesia language. Now 
most of the students in kindergarten take an English Course. It was unlawful. Poor kids, they need to learn about their culture itself, "said Musliar.

Whereas, in the context of a children cognitive development, language education must be taught as early as possible because of the golden age children language development is between 6 to 13 years (Elementary School period). Based on the research Brain Imaging Technology at the University of California, Los Angeles, cognitive processes, creativity, and divergent thinking in children are in optimum condition at the age of 6 to 13 years, so that biologically this time be the right time to maximize language learning foreign. Therefore, it is very unfortunate if this time simply overlooked.

Based on this issue, I have an idea tau idea to teach English at the elementary level while preserving and introducing Indonesian culture early on. The idea is a bilingual comic (bilingual) based on local wisdom from various regions in Indonesia as a media of English subject to young learners.

\section{LITERATURE REVIEW}

\section{Comic}

Comics are a visual communication media which have the power to convey information in a popular and easy to understand. This is possible because the comic combines the power of pictures and writings, which are arranged in a storyline. The picture makes easy to be absorbed, the text makes easy to be understood, and the flow makes easy to follow and remember. "Using comics as a media of learning are different from using a film or animation. Although the movie or animation is also a visual media, they can only be seen without being able to repeat it as we want. Comic is different from it, as a permanent media. Simply, if the students do not understand a feature film or animation, they could not repeat it. But by using comics, they can repeat. Besides comics selected in order to generate interest and relieve boredom children while learning

Comics are one type of reading which is favored by children because there is various interesting story which is also accompanied by pictures that can connect the reader's imagination. Rohani (1997: 78) argues that the comic is a cartoon that expresses a character and act out a story in sequence tightly linked to the image and is designed to provide entertainment to the readers.

Comics are a form of display message, consists of a variety of situations to serialize, sometimes humorous. Furthermore, according to Sudjana and Rival (2010: 64) comics can be defined as a form of cartoon that reveals the character and act out a story in order closely associated with the image, some disposition of the comic should be known that the strength of the medium could be understood. At the first, the title of comic devoted to a series of images in sequence and has linkages between the images with each other, sometimes assisted with writing that serves to reinforce the idea to be conveyed. Based on the linguistic, comic was from Greek language is a form of two-dimensional picture stories which tell the various stories and it is considered impossible to happen in the daily life.

Broadly speaking, according to Trimo (in Maryanah, 2005: 25) comics' media can be divided into 2 types. They are strip comic and book comic. Strip comic is a form of comic which consist of several sheets of frame columns published in a newspaper or magazine, the story is continued, while the comic book is comic which is formed in a book. The fundamental role of comic books in teaching is the ability to create the students' interest. The use of comics in teaching should be 
combined with teaching methods, so that the comic will be able to be an effective teaching tool. Comics are a form of reading in which children read it without having to be persuaded. Through the guidance of teachers, comics can serve as a bridge to foster interest in reading (Sudjana and Riva, 2010: 68). Using comics as a media of learning can direct learners to discipline of reading, especially those who do not like to read also be a bridge to read more serious books. According to Afrizal (2006: 2) activity and student learning outcomes using mathematical comic with the game is likely to increase. Comic can be useful media in teaching young learners to motivate them in English learning

\section{Local Wisdom}

Local wisdom consists of two words, they are wisdom and local. So, local wisdom is local ideas that are thoughtful, full of wisdom, good value, embedded and followed by members of the community. When it is viewed conceptually, local knowledge and local excellence are the human wisdom that rests on the philosophy of values, ethics, methods and behaviors that institutionalized traditionally. Sunaryo and Laxmnan (2003) said that local wisdom is the local knowledge that is so fused with a system of beliefs, norms and culture which is expressed in tradition and myth embraced in a long time.

Based on the above statement, it can be concluded that local wisdom is a truth that comes from the natural values to encourage and teach about how to 'read' the potential of natural and rewrites it as a tradition that is universally accepted by the public, especially in architecture. The traditional values harmonize of human life by respecting, nurturing, maintaining and preserving the natural environment.

The characteristic of local wisdom is able to withstand foreign cultures, has the ability to accommodate foreign cultures, has the ability to control, and has the ability to integrate elements of foreign culture into the native culture, capable members toward the cultural development.

\section{TEACHING ENGLISH FOR YOUNG LEARNERS}

In teaching English to young learners, in this case, the students of elementary school, the teachers must comprehend the concept of acquisition and learning. Acquisition can be defined as a process of having language naturally or sub-consciously. On the other hand, learning is a process of having language consciously. Krashen and Terrell, (1983: 18) in Sukarno (2008) state that acquiring a language is 'picking it up', i.e., developing ability in language by using it in natural, communicative situations. Children acquire their first language, and most probably, second languages as well. Language learning is different from acquisition. Language learning is 'knowing the rules', i.e., having a conscious knowledge about grammar. According to recent research, it appears that formal language learning is not nearly as important in developing communicative ability in second languages as previously thought

In line with children's development and the two concepts above (acquisition and learning), the teaching of English to young learners at elementary school requires situations in which the students acquire language abilities by means of acquisition rather than learning. It means that the students acquire language naturally and communicatively.

In the process of teaching English to young learners, or, students of elementary school, there are three points that must be considered and done. Those are as follows. 


\section{a. Language chunks}

In practicing speaking in English, the students need to use language chunks, i.e., phrases which have complete meaning. In this way, the students will be able to comprehend language function as a means of communication easily although at first they do not know the meaning of the phrases they use, such as,

"Good morning", "Good afternoon", "Never mind", "Thank you", and so forth. Perhaps, at the beginning the students do not know the meaning of the intended phrases but they comprehend the usage of those expressions. For example, when they meet their friends in the morning they will say, "Good morning", at noon they will say, "Good afternoon", when they are given something by their friends, they will say, "Thank you", and so forth. This is in line with Abe (1991: 266) who the language teachers to treat language as a series of natural chunks.

\section{b. Using media}

Using media as a means of teaching English to young learners helps the teachers create classroom situations to be more alive. The media also help the teachers render materials and help the students comprehend the given materials.

.... In place of reading, we can use flash cards, pictures, and various objects and realia to make the classroom come alive and resemble more closely the outside world. Use of these tools can free the teacher to be more the observer and facilitator and free the children to learn to use the language and learn to love the potentially fabulous experience of being able to communicate in another language to other people from around our vast word (Abe, 1991: 266-267).

\section{c. Topic-based activities}

Topic-based activities are usually called The Topic Approach (Hudelson, 1991: 258) or Topic-Based Work (Krashen, 1983: 84). The topic-based activities begin with a subject appropriate for the students and then that subject is designed to involve the students in investigating the topic and using the language as an integral part and the core of investigation. The topic approach begins with a subject that is of relevance and/or interest to the learners and then designs activities for learners that will involve them in investigating that topic and using language as an integral and central part.

\section{REVIEW OF PREVIOUS RESEARCH}

The using of comic as a learning media has done some of the researcher. They stated that there is an increasing of the students after the researcher apply comic in the school.

The first researcher is Atik Rokhayani, S. Pd, M. Pd. and Aisyah Ririn P. U., S. S, M. Pd. (2013). The title is Pembelajaran Bahasa Inggris dengan Printed Material Comic Strip sebagai media untuk Meningkatkan kosa kata siswa Sekolah Menengah pertama di Kudus. The result can be seen of vocabulary a test which is given to $7^{\text {th }}$ grade students in SMP 2 Bae Kudus involves two cycles. The first cycle showed that the average of the class is 76.97 and the average of second cycle is 85.10 . It proofs the successful in increasing vocabulary of students.

The effectiveness of comics as a media of learning viewed from two points of view involves the response of teachers and students of the cycle I and II. A comic strip is appropriate and effective media is used in learning process. It also impacts on the ability of students to understand the expressions which express by each character. They will find out the topic covered in the comic. So the conclusion can be drawn lines that appeal to the visualization of the characters in the 
comic can fulfill the students' needed in their interest, motivation to learn and entertainment due to the characteristic of comic is entertaining and educative. However, the weakness of comic is only describe that comics rely solely on visual side in order to stimulate the imagination of students on an educational story.

The second researcher is Ni Nyoman Padmadewi, Putu Kerti Nitiasih, Luh Putu Artini. Journal of Education and Teaching entitled Model Konseptual Pembelajaran Bahasa Inggris Berbasis Budaya Untuk Sekolah Dasar di Bali (2009). Learning English-based culture will play an important role in learning English to primary school which will provide a new atmosphere for students and can provide ease in learning English as a foreign language because the material in the theme and sub-themes have been adapted to the local culture of learners and other learning components is already adjusted to the level and capacity of learners. To get the maximum learning, the teachers' role in providing cultural content material is essential. Teachers are required to be able to present a fun learning so that students will be enjoying learning. In other words, the teacher is expected to choose the right strategy and effective in learning to organize and regulate the course of the learning process in order to form a persuasive learning, active, creative, empathic, and interesting.

\section{METHOD}

The data was used in arranging this paper is study literature related to the ideas is discussed. Some of the main references which are used: English language learning method, local wisdom, and scientist journal print edition and online editions, and articles are sourced from the internet.

The writing was pursued interconnected between each other and according to the topics discussed. The collected data were selected and sorted according to the study topic. Then do the preparation of papers based on the data that has been prepared logically and systematically. The data analysis technique is descriptive argumentative.

The conclusions obtained after referring back to the statement of the problem, the purpose of writing, and discussion. Conclusions were drawn to present the subject of writing, and supported with practical suggestions as subsequent recommendations.

\section{DISCUSSION}

Education is a system which has some components, such as teachers, students, methods and approaches. They must work together in harmony in order to achieve the learning objectives. The main purpose of education is to humanize humans or build one's character to be good and positive. In education is needed media to make easy in delivering material to the students. Thus, learning media is the components related to software and hardware that is used to convey messages from the communicator (the teacher) to the communicant (student / student) to stimulate the mind, feelings, concerns and interest in learning so that learning occurs. One of the learning media is comic. The using of comic is aimed to improve the ability of simple dialogue in English language learning.

Comics as a media of learning is considered effective to develop creativity in the field of visual communication design which have the power to convey information in a popular and easy to understand. This is possible because the comic combines the power of pictures and writings that are arranged in a picture story line that makes information more easily absorbed. The text makes 
it more understandable, and grooves making it easier to follow and remember. Today comics has been functioning as the entertainment media that can be aligned with various other kinds of entertainment such as movies, TV, and cinema.

By using comic, we are invited to know the environment to improve the taste of fantasy, imagination and creative spirit. Comic media has the potential to be a source of learning. The using of media in teaching and learning process is very important. There are several criteria in the selection to achieve the effective results. The criteria include:

1.Interesting, that the media used should be of interest to students.

2. Motivating, that the media used to motivate students to read,

3. Relevant / appropriate, that the media used should be relevant or appropriate to the topic discussed and in accordance with the age of the student.

The criteria-criteria should be used educators to get the expected results. However, comic is only entertainment media which can be aligned with various other kinds of entertainment such as movies, TV, and cinema. It shows that the content of the comic still give little moral values are very useful for readers. Therefore, the comic is potential as a media of learning English for young learners if it contains a lot of moral culture to teach and to love their own culture besides learning English. The contents of comic are still not able to provide a moral value and education value. It makes comic cannot be English learning media for young learners.

National Education Standards Agency (BSNP: 2006) states that language has a central role in the intellectual development, social, and emotional learners and it supports the success in studying the field of study. As for the language learning strategies that are expected to include: helping learners to know themselves, their culture, and the culture of others. In addition, language learning also helps learners is able to express ideas and feelings, participate in the society, and even find and use analytical and imaginative ability that was in him.

By using this method, the process of learning a foreign language would be easier to understand because there is a closeness theme with students. It can also be used as a vehicle to maintain local culture and local wisdom.

\section{DESIGN MANUFACTURE COMICS}

1. Screening and filtering the ideas

Filtering idea is the experiments stage and early design embodies the story of text into a story in a visual language. This phase is done in the form of a story draft to story episodes which is then translated into a visual language by making a storyboard.

2. Completing of the form

The draft storyboard is drawing on paper using a pencil, taking into account the visual element and applying the theory of comics.

3. Transferring the pictures

This stage is the stage of scanning (scanning) an image to be transferred into digital form by using a scanner (scanner) for further followed by an editing phase.

4. Editing

Editing stages is the stage of completion the quality by sharpening the image, enhancing the image, giving text and dialog by using computer applications Adobe Photoshop. 


\section{Printing}

The concept of the creation of the comic is usually realized in the form of a comic book in print. Completion of works by printing the pages of comics and posted. Before printing the book, all the files organized into CMYK mode so that the printout is maximal.

\section{Creative Objective}

The objectives of this design is as a media of learning English which is fun and introduce Indonesia culture both locally and nationally for young learners. Stories about our local wisdom will write with a wide variety of genres are comedy, romance, fantasy, and others. Level the story is presented by adjusting to the age of the child

\section{Characteristics of Target Readers}

The audience target of this digital comic is young leaner in Indonesia. Things that need to be considered is the characteristic of the target audience. They include:

a. Geographic: The location of a place

b. Demographics: the subject of the comic book

c. Psychographics: Understanding of the children characteristic

d. Behavioral: erosion of culture and they lack of English language skills

\section{Basic Concepts of Style Design}

\section{Media Concept}

Supporting media which is used to disseminate this comic media is the book of a thin shape to a thick book. Size of the book is $13.5 \times 20.5 \mathrm{~cm}$.

\section{Visual Concepts}

\section{a. Visual styles}

In designing of local wisdom comic, the author uses the style of cartoon images of children based on local customs. Cartoon style is selected because the comic genre because it is flexible generally preferred by all people. The specific characteristic is its dynamism and flexibility, according to local wisdom comic with a dynamic story.

b. Color

The color used in the depiction of this comic is black and white.

c. Style Layout

Style layout is a combination of text and images balloons organized by the panel. A text balloon there is one area that writes local alphabet and English. Layout on every single book is distinguished to make it is not monotonous. Layout adapted to the required image on each page as well as information to be conveyed.

3. The concept of the Plot and Moral Value

Stories will rise in this comic is local wisdom in Indonesia which is told in children style. The storyline of the comic book is mix because we wing plot because it will present the history local wisdom appears.

\section{Steps Teaching and Learning by using Comic}

Steps which are needed to be prepared as follows:

- Selecting of English learning materials by analyzing the standard competence, basic competence, and indicator.

- Analyzing the English language learning objectives to be achieved.

- Creating a lesson plan 
- carrying out the learning activities

- Developing an evaluation tool.

\section{Ways of Learning with Comic}

These are the ways that can be done by a teacher to make English learning more interesting by using media:

\begin{tabular}{|l|l|l|}
\hline No & \multicolumn{1}{|c|}{ Ability of English } & \multicolumn{1}{c|}{ The using of Comic } \\
\hline 1. & Reading & $\begin{array}{l}\text { - Students read comic } \\
- \text { Teacher reads comic by using interesting ways. } \\
\text { - Giving the questions for them about the story in } \\
\text { the comic to know their understanding. }\end{array}$ \\
\hline 2. & Writing & - Rewriting the story after they read the story \\
\hline 3. & Speaking & $\begin{array}{l}\text { Giving opportunity for students to retell the } \\
\text { comic which use short sentences.. } \\
\text { Taking picture and arranging the picture orderly. } \\
\text { Then, ask them retell based on the picture. }\end{array}$ \\
\hline 4. & Vocabulary & $\begin{array}{l}\text { Translating the sentences in comic into } \\
\text { Indonesian language. }\end{array}$ \\
\hline 5. & Grammar & $\begin{array}{l}\text { Recognizing, teaching, and taking example from } \\
\text { the sentences in the comic. }\end{array}$ \\
\hline
\end{tabular}

\section{CONCLUSION AND SUGGESTION}

Today, we live in literacy era which forces us to know any kind of information, one of them is media of learning. Therefore, as citizens of Indonesia who have culture should be able to create an update learning media but we still maintain our culture, in English learning. The components in designing this media consist of: comic makers, educators, and schools. Furthermore, we have to decide the goal, the concept of story, the concept of media, and the concept of visual (visual style, color, and layout style), characteristics of the audience, the plot and the moral value which will be delivered in a story. If all of them have been made, the next stage is implementation of the comic in English language learning activities. English language learning materials which can use the comics' media is reading, writing, speaking, vocabulary, and grammar. So by using this comic, readers and English language learners can learn English without ignore their culture and local wisdom.

\section{REFERENCES}

Afrizal. (2006). Upaya Meningkatkan Aktivitas dan Hasil Belajar Matematika Siswa Melalui Permainan dan Komik Matematika Pada Siswa Kelas III MI (SD) TGIA PERKEMAS

Teluk Betung Tahun Pelajaran 2005/2006. Universitas Lampung. Bandar Lampung. http://sosiologi.upi.edu/artikelpdf/dayakbakumpai.pdf http://vervalsp.data.kemdikbud.go.id http://www.deptan.go.id/dpi/detailadaptasi3.php http://www.ef.co.id/epi/

Hudelson, Sarah. (1991). EFL Teaching and Children: A Topic-Based Approach (The English Teaching Forum). Arizona State University, USA.

Krashen, Stephen D. and Terrell, Tracy D. 1983. The Natural Approach. New Jersey: Alemany Press Regent/Prentice Hall. 
Maryanah, Nur. (2005). Efektivitas Media Komik Dengan Media Gambar Dalam Pembelajaran Geografi Pokok Bahasan Perhubungan Dan Pengangkutan (Studi Eksperimen Pada Siswa Kelas VII Smp N I Pegandon Kabupaten Kendal). Skripsi Jurusan Geografi. UNS.

Dalam http://digilib.unnes.ac.id/gsdl/collect/skripsi/archives/HASH01b2/0a21b10d.dr/doc.pdf . 13 Januari 2011: 09.04.

Padmadewi, Ni Nyoman, Putu Kerti Nitiasih, and Luh Putu Artini. (2009). Model Konseptual Pembelajaran Bahasa Inggris Berbasis Budaya untuk Sekolah Dasar di Bali. Education and Teaching Journal, 42 (3): page 170 - 177.

Rohani, Ahmad. (1997). Media intruksional Edukatif. Jakarta: PT Rineka Cipta.

Rokhayani, Atik and Aisyah Ririn. (2013). Pembelajaran Bahasa Inggris dengan printed Material Comic Strips sebagai Media untuk Meningkatkan Kosa Kata Siswa Menengah Pertama di Kudus. Laporan Akhir Penelitian Dosen Pemula: Universitas Muria Kudus.

Scott, Wendy A. and Ytreberg, Lisbeth H. (1993). Teaching English to Children. Longman.

Sudjana and Rival. (2010). Dasar-dasar Proses Belajar, Sinar Baru Bandung Cerdas Berhitung $B S E$

Sukarno. (2008). Teaching English to Young Learners and Factors to Consider in Designing the Materials. 